\title{
PENGEMBANGAN KAWASAN BUDIDAYA JAGUNG UNTUK PENINGKATAN PEREKONOMIAN KABUPATEN PEMALANG
}

\author{
The Maize Cultivation Area Development for Pemalang Regency \\ Economy Improvement
}

\section{Eko Fitriono Harimurti ${ }^{1}$, Khursatul Munibah² and Untung Sudadi ${ }^{2}$}

\begin{abstract}
Abstrak: Kabupaten Pemalang memiliki tingkat perekonomian yang rendah, bertumpu pada sektor pertanian khususnya subsektor tanaman pangan dengan Padi dan Jagung sebagai kontributor utama, memiliki laju konversi sawah tinggi yang semakin memperburuk perekonomian melalui penurunan produksi Padi. Tujuan penelitian ini adalah menyusun perencanaan pengembangan kawasan budidaya Jagung untuk peningkatan perekonomian Kabupaten Pemalang. Metode yang digunakan adalah: pemetaan kondisi eksisting kawasan budidaya Jagung, evaluasi kesesuaian dan ketersediaan lahan, analisis ekonomi, pemasaran dan korelasi antara produksi Jagung dengan PDRB dan tenaga kerja. Hasil penelitian menunjukkan: terdapat 1.804 ha lahan pertanaman Jagung dan 4.276 ha lahan potensial pengembangan budidaya Jagung dengan kelas kesesuaian lahan sesuai marjinal (S3). Budidaya Jagung di lahan potensial layak dilanjutkan dengan keuntungan maksimal didapat melalui rantai pemasaran: Petani-Depot-Industri yang memiliki margin terendah dan farmer's share tertinggi. Pasar Jagung di Kabupaten Pemalang dalam kondisi terintegrasi. Pemanfaatan lahan potensial dan 285,66 ha lahan Perhutani diprediksi meningkatkan $5,94 \%$ PDRB sektor pertanian dan menyerap seluruh pengangguran di Kabupaten Pemalang.
\end{abstract}

\section{Kata kunci: Pengangguran, Pengembangan Jagung, PDRB}

\begin{abstract}
Pemalang Regency had low economic rate, based on agriculture sector especially food crop sub-sector with Paddy and Maize as main contributor, had a high paddy fields conversion wich decreased the economic rate through Paddy production decreasement. The main objective of this research were to compose the Maize cultivation area development planning for Pemalang Regency economy improvement. The method used in this research were: mapping the Maize cultivation existing area, land suitability and availability evaluation, analysis of economic, marketing and correlation between Maize production with GDP growth and employment absorption. The results showed that there were about 1,804 ha of exsisting Maize cultivation area and 4,276 ha marginally suitable (S3) potential land. The Maize development were be feasible to be continued. Best benifit obtained from the channel that composed by Farmer-Depot-Industry, it gave lowest margin and highest farmer's share. The Maize market in integrated condition. Allocation potential land and 285.66 ha of Perhutani's area predicted gave $5.94 \%$ of agriculture sector increasement and absorb all unemployment in Pemalang Regency.
\end{abstract}

Keywords: GDP, Maize development, Unemployment

\footnotetext{
${ }^{1}$ Program Studi Ilmu Perencanaan Wilayah, Sekolah Pascasarjana, Institut Pertanian Bogor

${ }^{2}$ Departemen Ilmu Tanah dan Sumberdaya Lahan, Fakultas Pertanian, Institut Pertanian Bogor
} 


\section{PENDAHULUAN}

Produk Domestik Regional Bruto (PDRB) merupakan salah satu indikator perekonomian wilayah (Rustiadi et al., 2011). Menurut Arsyad (1999), pembangunan perekonomian adalah usaha meningkatkan harkat martabat masyarakat dari kemiskinan dan keterbelakangan. Indikator kemiskinan suatu wilayah antara lain tingkat pendapatan masyarakat yang rendah dan angka pengangguran yang tinggi (Purwanto, 2007).

Menurut BPS Pemalang (2017), perekonomian Kabupaten Pemalang bertumpu pada 3 sektor utama yaitu: pertanian 27,97\%, industri 20,79\% dan perdagangan 14,77\%, dan kontribusi subsektor tanaman pangan terhadap PDRB sektor pertanian adalah yang tertinggi dari hasil produksi Padi dan Jagung. Padi sebagai kontributor tertinggi diprediksi akan mengalami penurunan produksi terkait konversi lahan sawah yang mencapai laju 2.761 ha sejak tahun 2010-2012 (Kementan, 2014). Oleh sebab itu, untuk meningkatkan kontribusi subsektor tanaman pangan diperlukan optimalisasi pemanfaatan lahan kering.

Kabupaten Pemalang memiliki lahan kering untuk pertanian seluas 18.558,60 ha atau 16,64\% dari luas Kabupaten (Bappeda Pemalang, 2017), berbatasan dengan kabupaten sentra industri (Tegal dan Pekalongan) dan dilalui jalur perekonomian nasional Pantura serta memiliki jaringan jalan yang bagus yang menghubungkan seluruh kawasan. Jagung merupakan salah satu indikator dalam Rencana Pembangunan Jangka Menengah Daerah Kabupaten Pemalang tahun 2011-2016 dan termasuk program pemerintah untuk ketahanan pangan (Pajale), mempunyai peluang pasar yang tinggi (Kementan, 2016) dan telah menjadi budaya pertanian di Kabupaten Pemalang (Wida et al., 2015). Oleh karena itu, Jagung memiliki potensi untuk dikembangkan sebagai usaha peningkatan perekonomian Kabupaten Pemalang.

Tujuan utama penelitian ini adalah menyusun perencanaan pengembangan kawasan budidaya Jagung untuk meningkatkan perekonomian Kabupaten Pemalang melalui usaha peningkatan PDRB sektor pertanian dan penyerapan tenaga kerja. Sedangkan tujuan antara untuk mencapai tujuan utama tersebut adalah: (1) menyusun peta sebaran eksisting kawasan budidaya Jagung, (2) menyusun peta kesesuaian dan ketersediaan lahan berpotensi untuk pengembangan kawasan budidaya Jagung, (3) menganalisis kelayakan ekonomi dan pemasaran Jagung. (4) Menganalisis keterkaitan antara produksi Jagung dengan peningkatan PDRB dan penyerapan tenaga kerja.

\section{METODE}

\section{Lokasi dan Waktu Penelitian}

Lokasi penelitian berada di Kabupaten Pemalang yang memiliki luas 111,530 ha. Secara astronomis terletak antara 109017'30"-109040'30" BT dan 8052'30"-7020'11" LS, dengan batas sebelah Utara, Selatan, Barat dan Timur berturut-turut adalah Laut Jawa, Kabupaten Purbalingga, Kabupaten Tegal, dan Kabupaten Pekalongan. Bulan Juli 2016Februari 2017. Lebih rinci lokasi penelitian tersaji pada Gambar 1.

\section{Data dan Metode}

Penelitian ini menghasilkan rencana pengembangan kawasan budidaya Jagung yang didapatkan melalui metode: (1) identifikasi kondisi eksisting sebaran spasial kawasan budidaya Jagung, (2) analisis kesesuaian dan ketersediaan lahan berpotensi pengembangan kawasan budidaya Jagung, (3) analisis ekonomi dan pemasaran Jagung (4) analisis keterkaitan produksi Jagung dengan peningkatan PDRB dan penyerapan tenaga kerja. Hubungan antara tujuan, jenis data, metode analisis dan hasil lebih rinci tersaji di Tabel 1. 


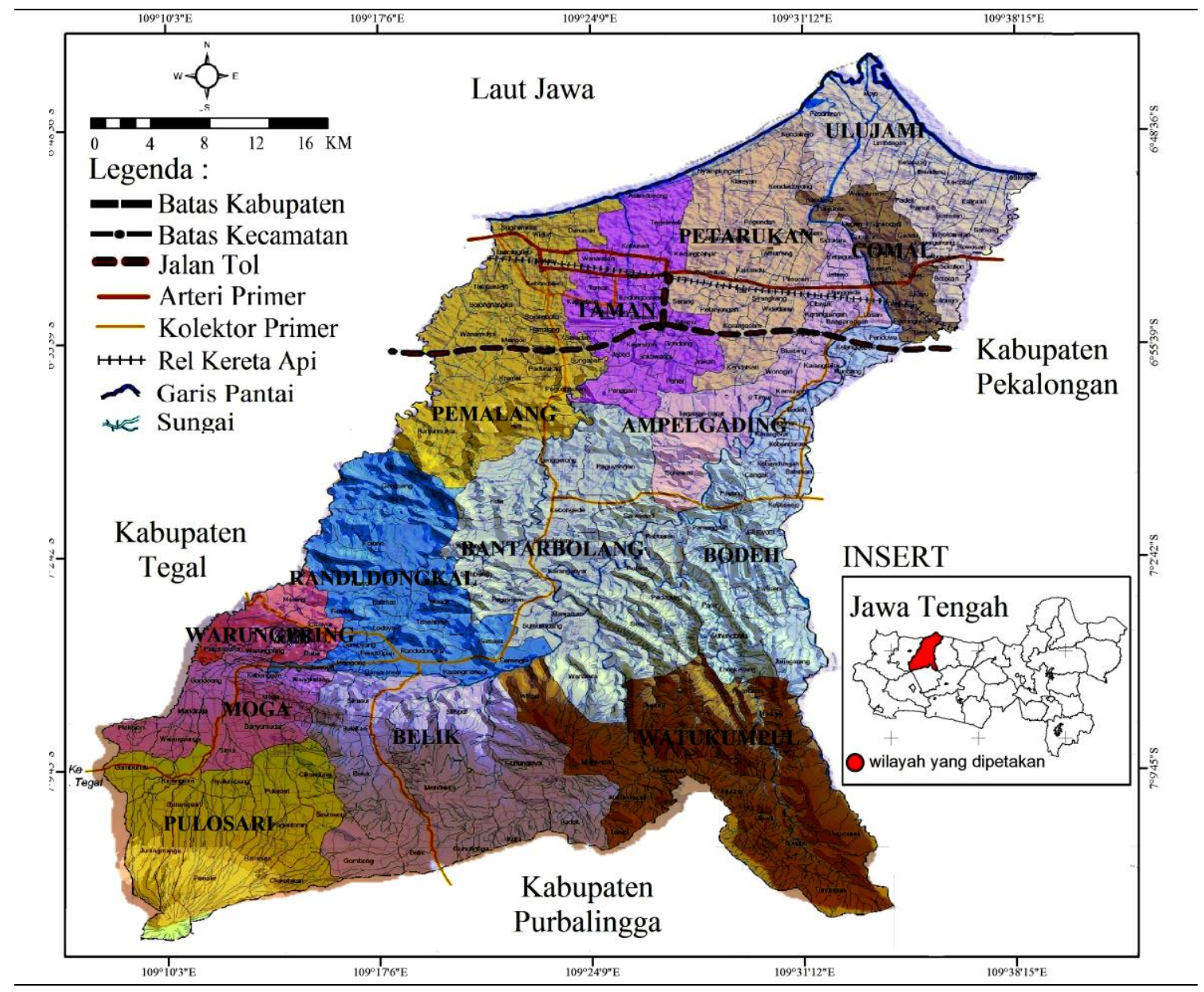

Gambar 1. Peta Lokasi Penelitian

Tabel 1. Hubungan antara Tujuan, Jenis Data, Metode dan Hasil

\begin{tabular}{|c|c|c|c|c|}
\hline No & Tujuan & Jenis Data & Metode Analisis & Output \\
\hline 1. & $\begin{array}{l}\text { Identifikasi kondisi eksisting } \\
\text { sebaran spasial kawasan } \\
\text { budidaya Jagung di Kabupaten } \\
\text { Pemalang. }\end{array}$ & $\begin{array}{l}\text { Luas dan sebaran spasial } \\
\text { pertanaman Jagung. }\end{array}$ & $\begin{array}{l}\text { Interpretasi Citra, } \\
\text { ground check dan } \\
\text { wawancara. }\end{array}$ & $\begin{array}{l}\text { Peta sebaran eksisting } \\
\text { kawasan budidaya Jagung di } \\
\text { Kabupaten Pemalang. }\end{array}$ \\
\hline 2. & $\begin{array}{l}\text { Analisis kesesuaian dan } \\
\text { ketersediaan lahan berpotensi } \\
\text { pengembangan budidaya Jagung } \\
\text { di Kabupaten Pemalang. }\end{array}$ & $\begin{array}{l}\text { Peta jenis tanah, pH, } \\
\text { Solum, Lereng, Curah } \\
\text { Hujan, Suhu, Pola Ruang, } \\
\text { Land use, Kawasan } \\
\text { Hutan dan output } 1 .\end{array}$ & $\begin{array}{l}\text { Analisis kecocokan } \\
\text { (Matching) dan } \\
\text { overlay. }\end{array}$ & $\begin{array}{l}\text { Peta kesesuaian lahan } \\
\text { berpotensi pengembangan } \\
\text { kawasan budidaya Jagung di } \\
\text { Kabupaten Pemalang. }\end{array}$ \\
\hline 3. & $\begin{array}{l}\text { Analisis ekonomi dan pemasaran } \\
\text { Jagung di Kabupaten Pemalang. }\end{array}$ & $\begin{array}{l}\text { Biaya dan harga jual } \\
\text { Jagung di setiap rantai } \\
\text { pemasaran. }\end{array}$ & $\begin{array}{l}\text { Usahatani, rantai, } \\
\text { margin, integrasi } \\
\text { pasar. }\end{array}$ & $\begin{array}{l}\text { Kelayakan, rantai, margin dan } \\
\text { integrasi pasar Jagung. }\end{array}$ \\
\hline 4. & $\begin{array}{l}\text { Analisis keterkaitan antara } \\
\text { produksi Jagung dengan PDRB } \\
\text { dan penyerapan tenaga kerja. }\end{array}$ & $\begin{array}{l}\text { Produksi Jagung, PDRB } \\
\text { dan tenaga kerja sektor } \\
\text { pertanian. }\end{array}$ & Analisis regresi. & $\begin{array}{l}\text { Keterkaitan produksi Jagung } \\
\text { dengan PDRB dan penyerapan } \\
\text { tenaga kerja. }\end{array}$ \\
\hline
\end{tabular}




\begin{tabular}{|c|c|c|c|}
\hline $\begin{array}{ll}\text { 5. } & \text { Menyusun perencanaan } \\
\text { pengembangan kawasan } \\
\text { budidaya Jagung untuk } \\
\text { peningkatan perekonomian } \\
\text { Kabupaten Pemalang. }\end{array}$ & $\begin{array}{l}\text { Output } 2,3 \\
\text { dan } 4\end{array}$ & $\begin{array}{l}\text { Deskriptif, studi } \\
\text { literatur, kondisi } \\
\text { pasar Jagung dan } \\
\text { regulasi terkait. }\end{array}$ & $\begin{array}{l}\text { Rencana pengembangan } \\
\text { kawasan budidaya Jagung } \\
\text { untuk peningkatan } \\
\text { perekonomian Kabupaten } \\
\text { Pemalang. }\end{array}$ \\
\hline
\end{tabular}

Analisis kondisi eksisting dilakukan dengan cara deliniasi visual berdasarkan bentuk, rona, warna dan asosiasi pada citra satelit beresolusi tinggi Spot 6 tahun akuisisi 2015, adanya jeda waktu akuisisi dengan pelaksanaan penelitian memungkinkan terjadinya ketidakakuratan hasil deliniasi, sehingga harus diverifikasi dengan ground check di seluruh lokasi penelitian dengan bantuan Google Map yang berfungsi untuk mempermudah proses identifikasi dan pengenalan lokasi. Output analisis ini adalah peta sebaran eksisting kawasan budidaya Jagung. Analisis ini diperkuat oleh penelitian Nahdi et al. (2014), Nurdina et al. (2016), Zamhari (2017) dan Purba (2017) yang menggunakan analisis yang sama pada pemetaan kondisi eksisting komoditas unggulan di penelitian masing-masing.

Analisis kesesuaian lahan dilakukan dengan mencocokan antara kondisi biofisik lahan dengan kriteria kesesuaian tanaman tertentu dan tindakan pengelolaan yang diperlukan (Sitorus, 2004, Hardjowigeno, Widiatmaka, 2007, Nowar et al., 2015) dalam topik ini adalah Jagung. Jagung tergolong tumbuhan $\mathrm{C} 4$ yang tidak memerlukan persyaratan khusus dan dapat dibudidayakan di berbagai jenis tanah termasuk di tahan masam (Samijan et al. 2010), (Suryaningsih et al., 2013). Tingkat keasaman (pH) tanah erat kaitannya dengan kapasitas tukar kation (KTK) yang merupakan indikator terbaik kesuburan tanah untuk tanaman Jagung (Parera, Weerasinghe, 2014), namun demikian dalam budidaya Jagung, pemupukan dan olah tanah merupakan paket manajemen dalam usaha meningkatkan hasil dan mereduksi faktor pembatas kesuburan tanah (Govind et al., 2015). Dengan demikian kriteria kesesuaian lahan yang digunakan adalah kesesuaian berdasarkan kriteria BBSDLP tahun 2011 yang mempunyai sifat sulit atau membutuhkan biaya tinggi untuk memanipulasinya (temperatur, curah hujan, drainase, tekstur, solum tanah, $\mathrm{pH}$, dan bahaya erosi)

Kategori lahan tersedia ditapis berdasarkan peruntukan pola ruang Rencana Tata Ruang Wilayah (RTRW) (Barus et al., 2011), status kawasan hutan (Widiatmaka et al., 2015) dan kondisi eksisting kawasan budidaya Jagung. Lahan tersedia adalah lahan berupa pertanian lahan kering padan kawasan non hutan dengan penggunaan lahan berupa sawah tadah hujan, tegalan dan semak. Alasan yang mendasari pengunaan lahan tersebut adalah produktivitas lahan yang masih relatif rendah dan dapat diusahakan lebih optimal. Overlay peta tanah, $\mathrm{pH}$, Solum, lereng, curah hujan, dan suhu pada lahan tersedia dan belum diusahakan komoditas Jagung menghasilkan peta kelas kesesuaian lahan berpotensi pengembangan budidaya Jagung. Metode ini diperkuat oleh penelitian Wirosoedarmo et al. (2011) yang menggunakan sistem informasi geografis (overlay) untuk melakukan evaluasi kesesuaian lahan tersedia untuk pertanaman Jagung di Kabupaten Blitar.

Usahatani digunakan untuk menentukan kelayakan usaha (Soekartawi, 2006). Oktaviana (2008) melakukan analisis usahatani Kentang di Kabupaten Semarang, Umikalsum (2013) melakukan analisis usahatani Padi di daerah agropolitan Waliksarimadu Kabupaten Pemalang dan Bardani et al. (2014) melakukan kelayakan usahatani Karet di Kabupaten Kutai Kartanegara dengan menggunakan analisis R/C ratio. Pengembangan kawasan budidaya Jagung di Kabuapten Pemalang dilakukan jika hasil analisis usahatani menunjukan perbandingan antara penerimaan $(R)$ dengan biaya yang dikeluarkan $(C)$ lebih dari 1 (R/C > 1). Nilai R dan $C$ dicari melalui Persamaan 1 dan 2.

Biaya (Cost):

$\mathrm{C}=\mathrm{FC}+\mathrm{VC}$ 
keterangan:

$\mathrm{C}($ Cost $) \quad$ Biaya total $(\mathrm{Rp})$
$\mathrm{VC}($ Variable Cost $) \quad=$ Biaya variabel $(\mathrm{Rp} /$ Unit $)$

$\mathrm{FC}$ (Fixed Cost) = Biaya tetap (Rp/Unit)

Pendapatan (Revenue):

$\mathrm{R}=\mathrm{Py} \cdot \mathrm{Y}$

keterangan :

$\begin{array}{lll}\mathrm{R} \text { (Revenue) } & =\text { Pendapatan } & \text { Py }(\text { Price })=\text { Harga Jual }(\mathrm{Rp}) \\ \mathrm{Y} \text { (Product) } & =\text { Produksi }(\mathrm{Kg} / \text { Unit }) & \end{array}$

Untuk mengetahui distribusi produk dari produsen hingga konsumen digunakan analisis rantai pemasaran (Lee, 2014), dalam penelitian ini dilakuan melalui survei dan wawancara kepada pelaku pengusahaan Jagung secara purposive sampling berdasarkan kelompok tani untuk menentukan produsen dan snowball sampling untuk menentukan konsumen. Margin pemasaran digunakan untuk mengetahui letak keuntungan tertinggi dari rantai pemasaran (Amri, 2015). Margin pemasaran dihitung menggunakan Persamaan 3. Untuk mengetahui persentase bagian harga yang diterima oleh petani dari harga di tingkat konsumen digunakan analisis Farmer's share yang juga menentukan tingkat efisiensi pemasaran (Fauziyah, 2011) yang dirumuskan dengan persamaan 4.

$M_{p}=P_{r}-P_{f}$ atau $M_{p}=B_{p}+K_{p}$

Keterangan:

$\mathrm{M}_{\mathrm{p}}=$ Margin pemasaran $(\mathrm{Rp} / \mathrm{kg})$

$\mathrm{K}_{\mathrm{p}}=$ Keuntungan pemasaran $(\mathrm{Rp} / \mathrm{kg})$

$\mathrm{P}_{\mathrm{r}}=$ Harga tingkat konsumen $(\mathrm{Rp} / \mathrm{kg})$

$\mathrm{P}_{\mathrm{f}}=$ Harga tingkat produsen $(\mathrm{Rp} / \mathrm{kg})$

$\mathrm{B}_{\mathrm{p}}=$ Biaya tataniaga $(\mathrm{Rp} / \mathrm{kg})$

$\mathrm{F}_{\mathrm{s}}=\frac{\mathbf{P}_{\mathbf{f}}}{\mathbf{P}_{\mathbf{r}}} \times 100 \%$

keterangan:

$\mathrm{F}_{\mathrm{s}}=$ farmer's share

$\mathrm{P}_{\mathrm{f}}=$ harga tingkat petani $(\mathrm{Rp} / \mathrm{kg})$

$\mathrm{P}_{\mathrm{r}}=$ harga tingkat konsumen $(\mathrm{Rp} / \mathrm{kg})$

Keterkaitan antara produksi Jagung dengan PDRB sektor pertanian, tenaga kerja dan perubahan yang disebabkan oleh korelasi antar variabel diketahui melalui analisis regresi (Ponto et al., 2015). Variabel yang digunakan adalah produksi Jagung dan PDRB sektor pertanian tahun 2011-2016. Secara rinci analisis regresi menghasilkan Persamaan 5.

$y=a+b x$

keterangan:

$\mathrm{y}=$ variabel akibat (response)

$\mathrm{b}=$ response yang ditimbulkan predictor

$\mathrm{a}=$ konstanta

$\mathrm{x}=$ variabel penyebab (predictor)

Analisis integrasi pasar digunakan untuk mengetahui efisiensi dan pembentukan harga suatu komoditas pada suatu tingkat lembaga pemasaran dipengaruhi oleh harga di tingkat lembaga pemasaran lainnya (Paul, Uebele, 2013). Variabel yang digunakan adalah harga Jagung di tingkat petani (produsen) dan industri (konsumen) tahun 2006-2016. Analisis integrasi pasar diukur dengan pendekatan metode Autoregressive Distributed Lag yang dikembangkan oleh Ravallion (1986) dan Heytens (1986) dengan menghitung Index of Market Connection (IMC) dari model regresi yang terbentuk (Amri, 2015). Secara rinci model regresi diuraikan sebagai Persamaan 6 dan IMC diformulasikan pada Persamaan 7. 
$\mathrm{P}_{\mathrm{it}} \quad=\mathrm{b}_{1}\left(\mathrm{P}_{\mathrm{it}-1}\right)+\mathrm{b}_{2}\left(\mathrm{P}_{\mathrm{jt}}-\mathrm{P}_{\mathrm{jt}-1}\right)+\mathrm{b}_{3}\left(\mathrm{P}_{\mathrm{jt}-1}\right)+\mu \mathrm{t}$

di mana:
$\mathrm{P}_{\text {it }} \quad=$ harga tingkat petani tahun $\mathrm{t}$
$\mathrm{P}_{\mathrm{jt}} \quad=$ harga tingkat industri tahun $\mathrm{t}$
$\mathrm{P}_{\mathrm{it}-1}=$ harga tingkat petani tahun sebelumnya
$\mathrm{t} \quad=$ periode waktu
$\mathrm{P}_{\mathrm{jt}-1}=$ harga tingkat industri tahun sebelumnya
$\mu \mathrm{t} \quad=$ error

IMC $\quad=b_{1} / b_{3}$

di mana:

$\mathrm{b}_{1} \quad=$ koefisien harga tingkat petani

$\mathrm{b}_{3} \quad=$ koefisien harga tingkat penjual

IMC $<1=$ terdapat integrasi jangka panjang yang relalif tinggi

IMC $=0$ = harga di tingkat ke-i pada waktu sebelumnya tidak berpengaruh terhadap harga yang diterima penjual pada pasar ke-i sekarang.

IMC $>1$ = antara pasar acuan dengan pasar ke- $\mathrm{i}$ tidak terintegrasi

\section{HASIL DAN PEMBAHASAN}

\section{Kondisi eksisting pertanaman Jagung}

Luas kawasan budidaya Jagung eksisting di Kabupaten Pemalang 1.804 ha, berpola memencar, luas kepemilikan rata-rata 1 bau $(0,74 \mathrm{ha})$, dan ada di seluruh kecamatan. Hal tersebut membuktikan bahwa Jagung merupakan komoditas favorit yang ditanam setelah Padi karena telah menjadi budaya pertanian di Kabupaten Pemalang (Wida et al., 2015). Secara rinci hasil pemetaan kondisi eksisting pertanaman Jagung tersaji pada Gambar 2.

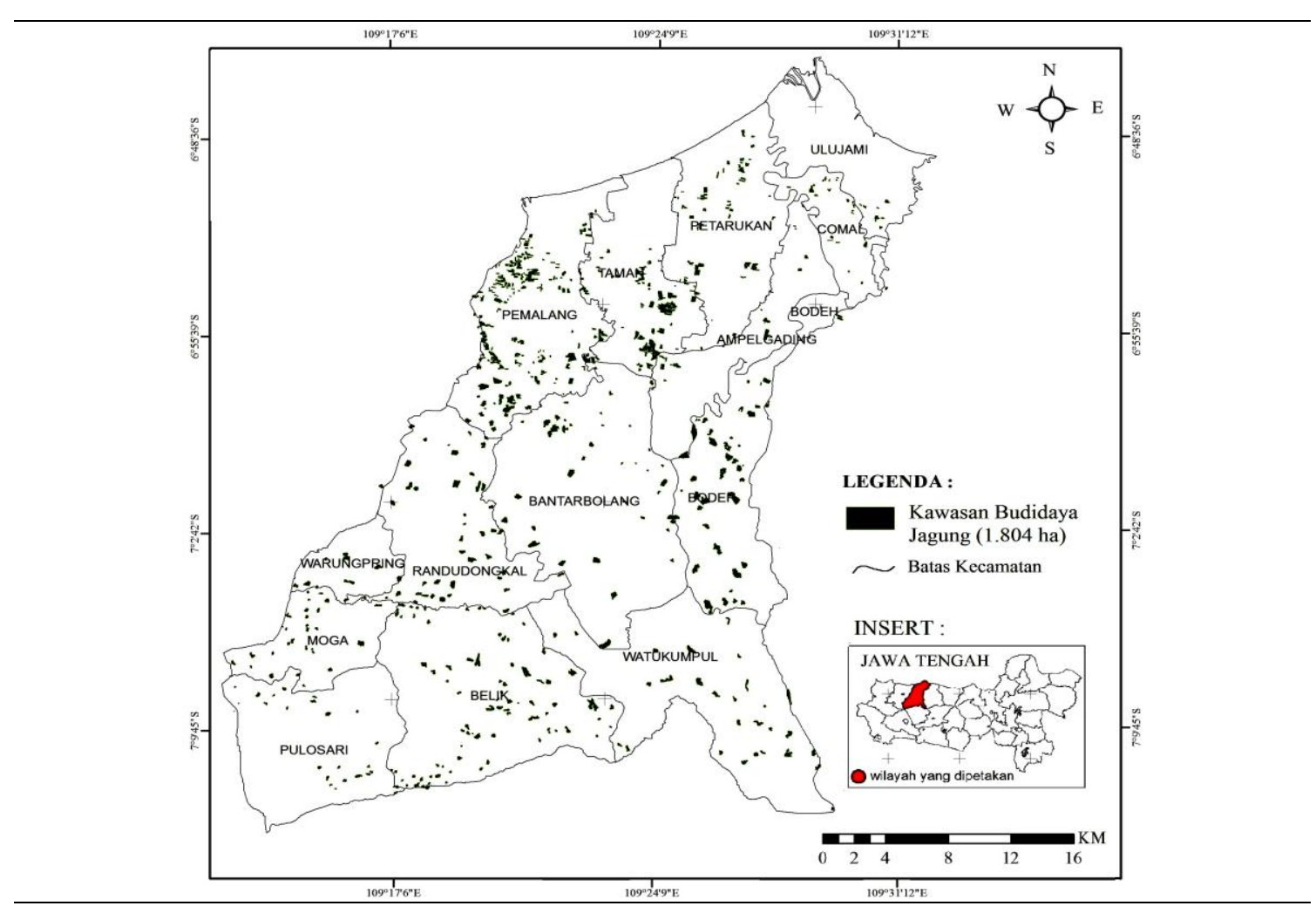

Gambar 2. Peta Eksisting Kawasan Budidaya Jagung

Kecamatan Pemalang, Petarukan dan Taman memiliki kawasan budidaya Jagung yang relatif luas dan kompak. Hal ini dikarenakan kecamatan tersebut termasuk dalam 
Satuan Wilayah Pembagunan (SWP) 1 yang merupakan pusat kota dengan infrastruktur yang langkap. Lahan di kawasan pusat kota mempunyai nilai ekonomi (locational rent) yang tinggi (Rustiadi et al., 2011), (Innocent et al., 2016). Desakan kebutuhan pangan dan harga sewa lahan relatif tinggi (Rp 20.000.000,-/ha/tahun) membuat petani memanfaatkan masa bera untuk bertanam Jagung yang merupakan komoditas tahan terhadap kekeringan. Masa bera seharusnya merupakan masa istirahat bagi lahan pertanian untuk memulihkan kesuburan tanah selama musim kemarau (Suryanto et al., 2006). Kondisi ini sejalan dengan hasil penelitian Gumma et al. (2016) yang menyatakan kebutuhan pangan yang meningkat di Asia selatan telah mengurangai masa bera lahan pertanian.

SWP 2 yang meliputi kecamatan Bantarbolang, Bodeh, Warungpring, Moga dan Randudongkal budidya Jagung dominan dibudidayakan di lahan Perhutani dengan pola tanam tumpangsari. Selain merupakan komoditas yang direkomendasikan, Jagung dipilih karena sifatnya yang mudah dan murah untuk dibudidayakan (Suryaningsih et al., 2013), (Sari, 2015) dan petani telah memiliki pengetahuan dan teknologi budidaya karena telah menjadi budaya pertanian di Kabupaten Pemalang (Wida et al., 2015).

Harga sewa lahan yang relatif rendah pada SWP 3 karena faktor jarak relatif jauh dari pusat kota yang meliputi kecamatan Belik, Pulosari dan Watukumpul membuat minat petani untuk mengusahakan lahannya kurang optimal. Hal ini sesuai dengan hasil penelitian Jordaan et al. (2004) yang menyatakan penurunan nilai ekonomi lahan sejalan dengan meningkatnya jarak dari pusat kota dan berkurangnya utilitas wilayah. Di kawasan SWP 3 budidaya Jagung umumnya dilakukan secara subsisten untuk memenuhi kebutuhan rumah tangga atau kebutuhan pakan ternak.

Budidaya Jagung di kawasan SWP 3 terkendala oleh belum adanya lembaga penampung hasil panen dan faktor jarak ke pasar Jagung yang relatif jauh sehingga menimbulkan biaya transportasi yang relatif tinggi. Kondisi ini merupakan peluang untuk pengembangan kawasan budidaya Jagung, disamping masih menyisakan lahan yang luas dengan locational rent yang relatif rendah, pengembangan budidaya Jagung yang diikuti pembangunan infrastruktur penunjang merupakan usaha yang sesuai dengan arahan pembembangan SWP 3 yaitu sebagai kawasan pengembangan potensi lokal yang meliputi pengembangan sektor pertanian lokal dan industri pertanian (Setda Pemalang, 2011).

\section{Kesesuaian Lahan Berpotensi Pengembangan Kawasan Budidaya Jagung}

Hasil evaluasi kesesuaian lahan hanya mendapatkan kelas kesesuaian sesuai marjinal (S3). Hal ini disebabkan karena adanya faktor pembatas curah hujan yang tinggi yang mendomisi diseluruh kawasan lahan tersedia untuk pengembangan budidaya Jagung di Kabupaten Pemalang. Tidak dijumpai kelas kesesuaian lahan tidak sesuai (N), hal ini disebabkan karena secara faktual faktor pembatas erosi yang disebabkan oleh faktor lereng telah teratasi dengan pembuatan terrasering. Curah hujan yang tinggi merupakan faktor alami yang sulit untuk dimanipulasi. Jagung memiliki banyak varietas dengan interaksi pertumbuhan yang berbeda di setiap kondisi cekaman air (Mazvimbakupa et al., 2015, Tshiabukole et al., 2017). Pemilihan varietas tahan terhadap cekaman air yang tinggi merupakan salah satu kunci keberhasilan pengembangan budidaya Jagung di Kabupaten Pemalang. Varietas Pioneer 21, Bima-3 dan Brasil dilaporkan sebagai varietas yang toleran terhadap cekaman air yang tinggi (Suwarti et al., 2013) dan varietas Nasa dilaporkan Kementan (2017) tahan terhadap curah hujan yang tinggi dan dapat meningkatkan hasil panen hingga $100 \%$. Secara lebih rinci hasil evaluasi kesesuaian lahan berpotensi pengembangan budidaya Jagung di Kabupaten Pemalang dapat dilihat pada Tabel 2 dan Gambar 3. 


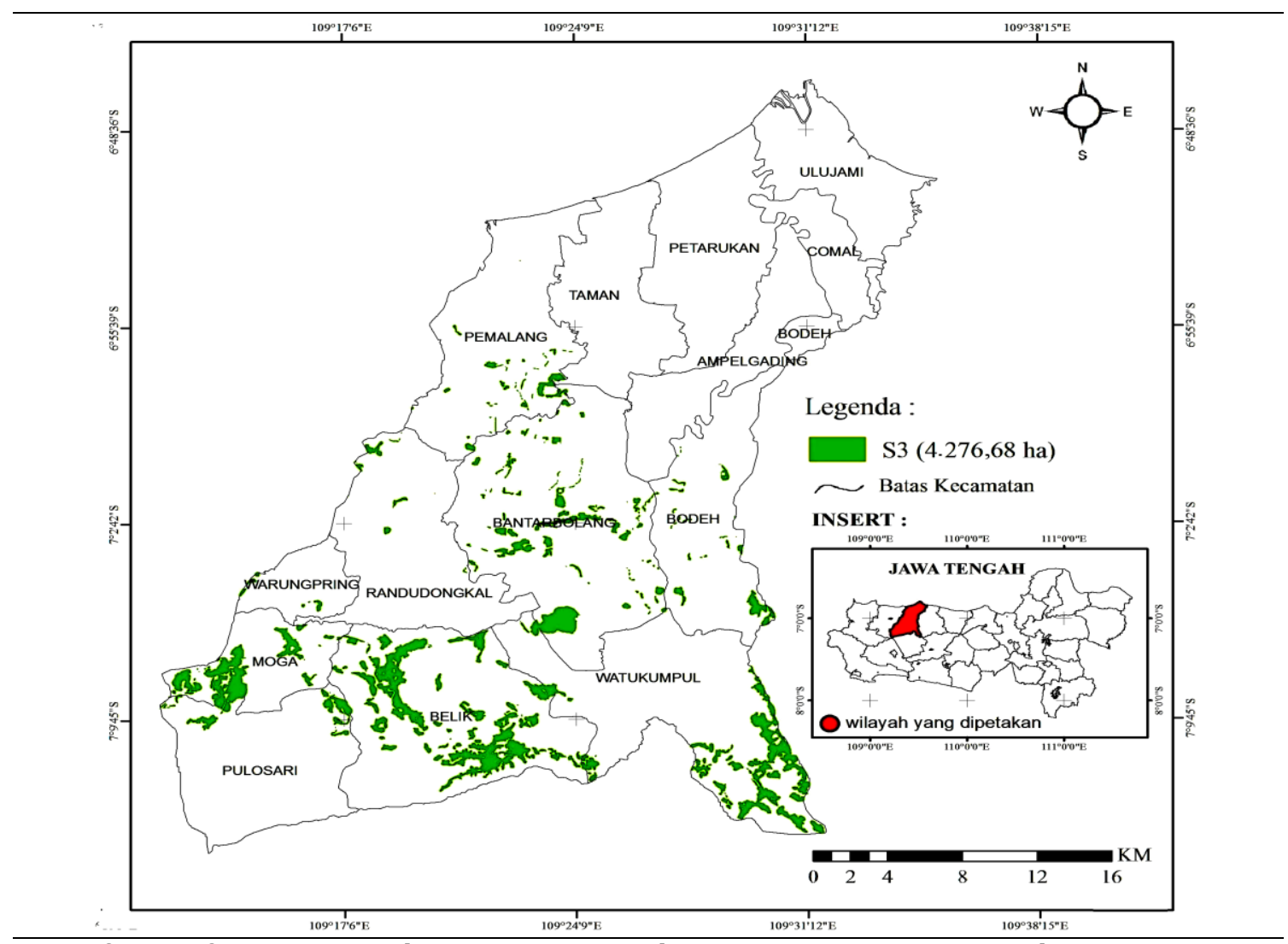

Gambar 3. Peta Kesesuaian Lahan Berpotensi Pengembangan Kawasan Budidaya Jagung

Tabel 2. Kesesuaian Lahan Berpotensi Pengembangan Budidaya Jagung di Setiap Kecamatan

\begin{tabular}{lclr}
\hline Kecamatan & Kesesuaian & Faktor Penghambat & Luas (ha) \\
\hline Pemalang & S3 & Curah Hujan & 91,66 \\
Moga & & Curah Hujan dan pH & 65,41 \\
& S3 & Curah Hujan & 577,08 \\
Pulosari & & Curah Hujan dan Tekstur & 64,21 \\
& S3 & Curah Hujan & 352,33 \\
& & Curah Hujan dan Temperatur & 32,62 \\
Belik & & Curah Hujan dan Tekstur & 35,81 \\
& S3 & Curah Hujan & $1.441,72$ \\
Watukumpul & & Curah Hujan dan Tekstur & 40,15 \\
& S3 & Curah Hujan & 897,99 \\
& & Curah Hujan dan Temperatur & 41,39 \\
Warungpring & & Curah Hujan dan Tekstur & 75,02 \\
Bodeh & S3 & Curah Hujan & 25,63 \\
Bantarbolang & S3 & Curah Hujan & 154,77 \\
& S3 & Curah Hujan & 408,89 \\
\hline
\end{tabular}

Persebaran lahan berpotensi pengembangan Jagung di wilayah kecamatan Pemalang, Taman, memiliki luas yang sempit, bahkan tidak dijumpai pada kecamatan Petarukan, Comal, Ulujami dan Ampelgading. Kondisi ini disebabkan kecamatan tersebut termasuk dalam SWP 1 yang diarahkan sebagai pusat kota dan hinterland yang memiliki infrastruktur lengkap termasuk infrastruktur pertanian. Lahan di wilayah SWP 1 umumnya memiliki dukungan irigasi yang memadai sehingga diprioritaskan sebagai Lahan Pertanian Pangan Berkelanjutan (LP2B) dan cadangannya untuk mendukung program ketahanan 
pangan baik daerah maupun nasional yang ditetapkan melalui Peraturan Daerah Kabupaten Pemalang No 3 Tahun 2011 (Setda Pemalang, 2011).

Kawasan SWP 2 yang meliputi kecamatan Bantarbolang, Bodeh, Warungpring, dan Randudongkal memiliki lahan berpotensi pengembangan budidaya Jagung yang relatif sempit dengan pola menyebar, hal tersebut dikarenakan adanya lahan konsesi pengusahaan Hutan Tanaman Industri oleh Perum Perhutani (Perhutani). Lahan Perhutani tidak termasuk dalam kategori tersedia untuk pengembangan kawasaan budidaya Jagung di Kabupaten Pemalang, namun merupakan lahan berpotensi cadangan karena lahan tersebut termasuk dalam kawasan hutan dan memiliki produk bernilai lebih tinggi dari Jagung namun secara faktual telah dilakukan usaha pertanian sebagai bentuk Corporate Social Responsibility (CSR) melalui program Pengelolaan Hutan Bersama Masyarakat (PHBM) dengan salah satu kegiatannya adalah tumpangsari wanatani (Perhutani, 2009).

Kecamatan Belik, Moga, dan Watukumpul termasuk dalam SWP 3 yang merupakan kecamatan dengan lahan berpotensi pengembangan budidaya Jagung yang lebih luas dan kompak (spatialy contiguous) sehingga mudah dalam pengelolaan wilayah (Rustiadi et al., 2011). Kondisi yang demikian memungkinkan untuk dilakukannya program ekstensifikasi yang dapat diusahakan secara komunal atau dengan skala yang lebih besar (skala perusahaan). Sesuai arahan pengembangan dan fungsi dari SWP 3, pengembangan kawasan budidaya Jagung di kecamatan tersebut diharapkan dapat meningkatkan perekonomian daerah melalui usaha pengembangan potensi lokal yaitu pengembangan sektor pertanian dan tumbuhnya industri pertanian (agro industri) (Setda Pemalang, 2011).

\section{Usahatani}

Budidaya Jagung di setiap jenis penggunaan lahan adalah layak untuk dikembangkan (R/C ratio $>1$ ). Walaupun memiliki keuntungan tinggi, lahan sawah irigasi dan tumpangsari Perhutani tidak termasuk lahan tersedia dalam menyusun rencana pengembangan. Kedua lahan tersebut mempunyai fungsi pokok lain dan menghasilkan produk yang bernilai lebih tinggi dari Jagung, yaitu Padi dan kayu pertukangan. Lahan tumpangsari pada kawasan Perhutani dijadikan sebagai lahan berpotensi cadangan karena secara faktual lahan Perhutani ditanam Jagung dengan pola tumpangsari (Perhutani, 2009). Dengan batasan tersebut, maka sawah tadah hujan merupakan lahan yang memberikan keuntungan maksimimal (Rp 5.549.000/ha/musim) disusul dengan lahan tegalan (Rp 5.325.000/ha/musim) dan lahan semak/belukar (Rp 5.295.000/ha/musim). Secara lebih rinci hasil analisis usahatani tersaji pada Tabel 3.

Tabel 3. Matriks Hasil Analisis Usahatani Jagung di Setiap Penggunaan Lahan 1 Musim Tanam

\begin{tabular}{lrrrrr}
\hline \multicolumn{1}{c}{$\begin{array}{c}\text { Penggunaan Lahan } \\
\text { Land use }\end{array}$} & $\begin{array}{r}\text { Produksi } \\
(\mathrm{kg} / \mathrm{ha})\end{array}$ & $\begin{array}{r}\text { Penerimaan } \\
(\mathrm{Rp} / \mathrm{ha})\end{array}$ & $\begin{array}{r}\text { Biaya } \\
(\mathrm{Rp} / \mathrm{ha})\end{array}$ & $\begin{array}{r}\text { Keuntungan } \\
(\mathrm{Rp} / \mathrm{ha})\end{array}$ & $\begin{array}{r}\mathrm{R} / \mathrm{C} \\
\text { ratio }\end{array}$ \\
\hline Sawah irigasi & 4.100 & 14.965 .000 & 7.596 .000 & 7.368 .000 & 1,97 \\
Sawah tadah hujan & 3.500 & 12.775 .000 & 7.226 .000 & 5.549 .000 & 1,76 \\
Tegalan & 3.500 & 12.775 .000 & 7.450 .000 & 5.325 .000 & 1,71 \\
Semak/belukar & 3.150 & 11.415 .000 & 6.120 .000 & 5.295 .000 & 1,86 \\
Tumpangsari Perhutani & 4.000 & 14.600 .000 & 7.832 .000 & 6.768 .000 & 1,86 \\
\hline
\end{tabular}

Komponen biaya pada analisis usahatani bervariasi menurut jenis penggunaan lahan. Sawah tadah hujan di Kabupaten Pemalang memiliki nilai ekonomis tertinggi dibanding land use tersedia lainnya sehingga menimbulkan biaya sewa yang tinggi, namun memiliki biaya penyiapan lahan yang relatif rendah karena kondisi lahan umumnya bersih sehingga menghasilkan keuntungan lebih tinggi. Lahan tegalan di Kabupaten Pemalang umumnya dimanfaatkan sebagi kebun campur. Pengusahaan Jagung pada lahan tegalan dilakukan secara tumpangsari sehingga membutuhkan biaya persiapan lahan untuk 
mengatur ruang tanam. Budidaya Jagung di lahan tegalan memiliki keterbatasan jumlah batang yang ditanam sehingga memberikan keuntungan yang lebih rendah dari lahan sawah tadah hujan. Tahir, Suddin (2017) memperkuat hasil penelitian ini dengan mengemukakan bahwa keuntungan budidaya Jagung yang didapatkan dari lahan sawah tadah hujan lebih tinggi dari tegalan.

Semak/belukar merupakan lahan dengan nilai ekonomis rendah, umumnya dalam kondisi belum dimanfaatkan secara optimal dan memiliki harga sewa lahan relatif mendah. Walaupun memiliki R/C ratio tertinggi dari land use tersedia lainnya, gangguan gulma yang tumbuh dari sisa persiapan lahan diduga mengakibatkan produktivitas Jagung menjadi rendah sehingga keuntungan yang didapatkan kecil. Ganguan gulma yang tinggi pada lahan bekas semak belukar dikarenakan kurang bersihnya kegiatan penyiapan lahan sehingga banyak menyisakan biji atau materi vegetatif gulma yang dapat tumbuh dan bersaing dengan tanaman Jagung. Hasil penelitian gangguan gulma terhadap penurunan produksi Jagung yang dilaporkan oleh Suryaningsih et al. (2013) dan Alvionita et al. (2015) memperkuat faktor penyebab tingkat produksi Jagung di lahan semak/belukar yang rendah dalam penelitian ini.

\section{Rantai dan Margin Pemasaran}

Terdapat 4 jenis rantai pemasaran Jagung di Kabupaten Pemalang, melebihi penelitian Cristoporus, Sulaeman (2009) di Kabupaten Donggala yang hanya sebanyak 2 jenis rantai pemasaran dan penelitian Hadijah (2009) di Nusa Tenggara Barat yang hanya mendapatkan 3 jenis rantai pemasaran. Rantai pemasaran Jagung di Kabupaten Pemalang secara rinci dapat dilihat pada Tabel 4.

Tabel 4. Matriks Rantai dan Margin Pemasaran Jagung di Kabupaten Pemalang

\begin{tabular}{clccc}
\hline Jenis & Simpul Rantai Pemasaran & $\begin{array}{c}\text { Margin } \\
(\mathrm{Rp} / \mathrm{kg})\end{array}$ & $\begin{array}{c}\text { Margin } \\
(\%)\end{array}$ & $\begin{array}{c}\text { Farmer's } \\
\text { Share }(\%)\end{array}$ \\
\hline 1 & Petani - Tengkulak - Depot - Industri & 1.500 & 31,91 & 68,09 \\
2 & Petani - Depot - Industri & 1.000 & 21,28 & 78,72 \\
3 & Petani - Tengkulak - Pengecer - Konsumen & 2.800 & 46,67 & 53,33 \\
4 & Petani - Pengecer - Konsumen & 2.000 & 33,33 & 66,67 \\
\hline
\end{tabular}

Keuntungan maksimal bagi petani didapat melalui rantai pemasaran 2 (Petani Depot - Industri), karena memiliki margin pemasaran terendah $(21,28 \%)$ dan nilai farmer's share tertinggi (78,72\%) (Yuprin, 2009), hal ini disebabkan karena: (1) Petani hanya melalui satu pedagang perantara yaitu depot untuk menyalurkan produk Jagungnya ke industri sehingga menimbulkan biaya pemasarannya tidak terlalu tinggi. (2) Petani mendapat kemudahan dari depot yang mengambil produk Jagung di rumah petani apabila jumlahnya banyak. Dengan demikian, sistem pemasaran jagung dengan menggunakan rantai pemasaran 2 memberi keadilan kepada petani.

Walaupun rantai pemasaran 2 merupakan rantai pemasaran yang paling efisien, namun secara umum petani Jagung di Kabupaten Pemalang belum menggunakan jenis rantai pemasaran ini, hanya petani di Kecamatan Pemalang saja yang menggunakan rantai pemasaran 2 karena didukung oleh faktor jarak yang relatif dekat dengan depot. Secara umum petani Jagung di Kabupaten Pemlang cenderung menjual hasil panen kepada tengkulak yang datang ketempat mereka dengan sistem pembayaran tunai atau kepada agen saprodi pertanian di mana mereka memperoleh pinjaman modal walaupun memberi keuntungan yang rendah yang tercermin dari margin pemasaran yang tinggi (Yuprin, 2009). Hal ini sejalan dengan pola pemasaran Jagung di Kabupaten Grobogan yang dilaporkan oleh (Widiastuti, Hasirudin, 2013).

Rantai pemasaran 3 (Petani - Tengkulak - Pengecer) adalah jenis rantai pemasaran yang terburuk karena memiliki margin tertinggi (Rp 2.800,-) dan farmer's share terrendah 
(53,33\%). Kondisi tersebut dikarenakan oleh adanya keterikatan antara petani dengan tengkulak. Peran tengkulak yang besar dan mendominasi disebabkan oleh pola pengusahaan Jagung yang masih bersifat individu dengan nilai transaksi yang relatif rendah dan membutuhkan hasil penjualan secara tunai. Strategi bisnis door to door yang dilakukan tengkulak sangat efektif menjangkau para petani Jagung yang berada jauh dari pusat kota (pasar). Peran tengkulak yang memberikan pinjaman modal menimbulkan keterikatan pemasaran bagi petani Jagung di Kabupaten Pemalang. Keterikatan tersebut membuat petani menerima harga yang rendah yang ditetapkan tengkulak. Hal ini senada dengan hasil penelitian Ardiani (2009) yang menganalisis rantai pasok di kawasan sentra produksi Jagung Indonesia.

\section{Integrasi Pasar}

Analisis autoregresive distribution lag yang dilakukan di tingkatan harga pasar rujukan dengan tingkatan harga di pasar produsen pada beberapa tenggang waktu, menghasilkan nilai integrasi pasar (Fauziyah, 2011). Dalam analisis dengan cakupan yang lebih luas, analisis integrasi pasar digunakan pada beberapa komoditas yang memiliki pemasaran global/internasional (Kusnanto et al., 2012). Dalam penelitian ini pemasaran dibatasi pada pasar tingkat industri yang merupakan pasar rujukan dan petani sebaga pasar tingkat produsen. Secara rinci harga Jagung 10 tahun terakhir dapat dilihat pada Tabel 5 dan parameter serta persamaan hasil analisis integrasi pasar tersaji pada Tabel 6.

Tabel 5. Matriks Harga Jagung di Kabupaten Pemalang

\begin{tabular}{rccccr}
\hline Tahun & $\begin{array}{c}\text { Harga tingkat } \\
\text { petani saat ini } \\
(\mathrm{Rp} / \mathrm{Kg})\end{array}$ & $\begin{array}{c}\text { Harga tingkat } \\
\text { petani sebelumnya } \\
(\mathrm{Rp} / \mathrm{Kg})\end{array}$ & $\begin{array}{c}\text { Harga tingkat } \\
\text { industri saat ini } \\
(\mathrm{Rp} / \mathrm{Kg})\end{array}$ & $\begin{array}{c}\text { Harga tingkat } \\
\text { industri } \\
\text { sebelumnya } \\
(\mathrm{Rp} / \mathrm{Kg})\end{array}$ & $\mathrm{P}_{\mathrm{jt}-1}$ \\
\hline 2006 & 1.802 & $\mathrm{P}_{\mathrm{it}-1}$ & $\mathrm{P}_{\mathrm{jt}}$ & $\mathrm{P}_{\mathrm{jt}-1}$ \\
\hline 2007 & 2.238 & 1.543 & 2.164 & 1.543 & 362 \\
2008 & 2.501 & 1.802 & 2.631 & 2.164 & 393 \\
2009 & 2.745 & 2.238 & 3.573 & 2.631 & 1.071 \\
2010 & 2.934 & 2.501 & 3.952 & 3.573 & 1.207 \\
2011 & 3.107 & 2.745 & 4.616 & 3.952 & 1.682 \\
2012 & 4.093 & 2.934 & 4.885 & 4.616 & 1.778 \\
2013 & 3.486 & 3.107 & 5.501 & 4.885 & 1.408 \\
2014 & 3.670 & 4.093 & 5.727 & 5.501 & 2.241 \\
2015 & 3.778 & 3.486 & 5.786 & 5.727 & 2.116 \\
2016 & 3.845 & 3.670 & 6.194 & 5.786 & 2.416 \\
\hline
\end{tabular}

Tabel 6. Matriks Hasil Dugaan Parameter Integrasi Pasar Jagung di Kabupaten Pemalang

\begin{tabular}{lrr}
\hline Variabel Bebas/Peubah & $\begin{array}{c}\text { Pamameter } \\
\text { Dugaan (beta) }\end{array}$ & $\begin{array}{c}p_{-} \text {value } \\
\text { (Significance) }\end{array}$ \\
\hline Bedakala harga Jagung di tingkat petani $\left(\mathrm{P}_{\mathrm{it}-1}\right)$ & 0,003 & 0,993 \\
Selisih harga Jagung di tingkat industri $\left(\mathrm{P}_{\mathrm{jt}}-\mathrm{P}_{\mathrm{jt}-1}\right)$ & 0,851 & 0,007 \\
Bedakala harga Jagung di tingkat industri $\left(\mathrm{P}_{\mathrm{jt}-1}\right)$ & 0,567 & 0,018 \\
\hline Persamaan: $\mathrm{P}_{\mathrm{it}}=0,003 \mathrm{P}_{\mathrm{it}-1}+0,851\left(\mathrm{P}_{\mathrm{jt}}-\mathrm{P}_{\mathrm{jt}-1}\right)+0,567\left(\mathrm{P}_{\mathrm{jt}-1}\right)$ & & \\
\hline Koefisien Determinasi $\left(\mathrm{R}^{2}\right)$ & 0,957 \\
$\mathrm{IMC}$ & 0,005 \\
\hline
\end{tabular}

Nilai koefisien Selisih harga Jagung di tingkat industri 0,851 pada persamaan regresi menunjukkan tingkat elastisitas transmisi harga. Nilai ini menunjukan jika terjadi perubahan harga sebesar Rp 10/kg di tingkat industri, maka akan diteruskan ke tingkat 
petani sebesar Rp 8,51/kg (85,1\%), dengan faktor lain dianggap tetap (ceteris paribus). Hal ini mencerminkan transmisi harga yang baik oleh pihak Industri.

Nilai IMC menunjukan hasil yang rendah 0,005, berarti pasar di tingkat petani dan industri terintegrasi dengan baik yang menunjukkan bahwa pasar dalam kondisi persaingan sempurna. Kondisi ini dipengaruhi oleh lancarnya arus informasi, barang dan jasa di wilayah Kabupaten Pemalang. Fasilitas telekomunikasi yang menjangkau seluruh wilayah Kabupaten Pemalang membuat perubahan harga di tingkai industri dapat segera diketahui oleh petani sehingga mendapat respon naiknya faktor-faktor pembentuk harga di tingkat petani, hal ini sejalan dengan laporan akhir Kemendag (2016) yang menyatakan bahwa arus informasi mendukung pembentukan harga di tingkat produsen (petani).

\section{Analisis Keterkaitan Produksi Jagung dengan PDRB Sektor Pertanian dan Tenaga Kerja}

Hasil analisis regresi pada kondisi produksi Jagung, PDRB sektor pertanian dan jumlah tenaga kerja di sektor pertanaian 6 tahun terakhir dan persamaan yang terbentuk dapat dilihat pada Tabel 6 dan 7.

Tabel 7. Korelasi Produksi Jagung dengan PDRB Sektor Pertanian

\begin{tabular}{crr}
\hline \multicolumn{1}{c}{ Variabel Bebas/Peubah } & $\begin{array}{c}\text { Pamameter } \\
\text { Dugaan (beta) }\end{array}$ & $\begin{array}{c}\text { p_value } \\
\text { (Significance) }\end{array}$ \\
\hline Produksi Jagung & 4.217 & 0,01 \\
Konstanta & -8.187 .763 & 0,03 \\
\hline Persamaan: $\mathrm{y}=-8.187 .763+4.217 \mathrm{x}$ & & \\
\hline $\mathrm{t}$ - hitung & & 10,17 \\
$\mathrm{r}$ & 0,98 \\
Koefisien Determinasi (R $\left.{ }^{2}\right)$ & 0,96 \\
\hline
\end{tabular}

Dari hasil analisis tampak bahwa koefisien korelasi bernilai positif sebesar 0,98 yang berarti ada hubungan yang sangat erat antara kenaikan produksi Jagung diikuti dengan kenaikan PDRB. Tingginya kontribusi dapat dilihat dari nilai koefisien determinasi 0,96 yang berarti peningkatan PDRB sektor pertanian 96\% dipengaruhi oleh peningkatan produksi jagung dan $4 \%$ sisanya dipengaruhi oleh faktor lain. Nilai t hitung yang lebih besar dari t tabel pada tingkat kepercayaan $5 \%(10,17>2,35)$ menunjukan adanya hubungan yang signifikan antara kenaikan produksi Jagung yang diikuti dengan kenaikan PDRB. Dari persamaan regresi yang terbentuk dapat dijelaskan bahwa, koefisien regresi variabel produksi Jagung sebesar 4.217, yang berarti jika produksi mengalami kenaikan $1 \mathrm{~kg}$, maka PDRB akan meningkat sebesar Rp 4.217, ceteris paribus.

Kondisi tersebut sesuai fakta bahwa PDRB sub sektor tanaman pangan mengalami peningkatan sejak tahun 2011-2016 dari Rp 3.248.406.000.000 hingga Rp 5.490.139.000.000 (BPS Pemalang, 2017). Walaupun PDRB sub sektor tanaman pangan mengalami peningkatan seiring peningkatan produksi Jagung, namun panen Jagung pada tahun 2016 hanya 5.888 ton (8,37\%), jumlah tersebut masih jauh di bawah hasil panen Padi yang mencapai 63.431 (90\%). Kondisi yang demikian disebabkan karena Jagung hanya dibudidayakan pada lahan seluas 1.804 ha dan berpola menyebar (Gambar 2).

Selain PDRB yang tinggi, keberhasilan pembangunan perekonomian wilayah diukur dengan meningkatkan harkat martabat masyarakat dari kemiskinan dan keterbelakangan. Salah satu indikator kemiskinan suatu wilayah antara lain tingginya angka pengangguran (Purwanto, 2007). Analisis regresi antara peningkatan produksi Jagung dengan penyerapan tenaga kerja beserta persamaan yang terbentuk dapat dilihat pada Tabel 8 . 
Tabel 8. Korelasi Produksi Jagung dengan Tenaga Kerja

\begin{tabular}{lrc}
\hline \multicolumn{1}{c}{ Variabel Bebas/Peubah } & Pamameter Dugaan (beta) & $P_{-}$value (Significance) \\
\hline Produksi Jagung & 0,02 & 0,85 \\
Konstanta & 506.412 & 0,11 \\
Persamaan: $\mathrm{y}=506.412+0,02 \mathrm{x}$ & & \\
t- hitung & 0,24 \\
$\mathrm{r}$ & 0,34 \\
Koefisien Determinasi ( $\left.\mathrm{R}^{2}\right)$ & 0,12 \\
\hline
\end{tabular}

Analisis regresi antara produksi Jagung terhadap penyerapan tenaga kerja sektor pertanian menghasilkan hasil koefisien korelasi bernilai positif sebesar 0.34 yang menggambarkan adanya hubungan yang lemah antara kenaikan produksi Jagung yang diikuti dengan kenaikan jumlah tenaga kerja. Tingginya kontribusi kenaikan produksi Jagung terhadap penyerapan tenaga kerja dapat dilihat dari nilai koefisien determinasi 0,12 yang berarti peningkatan jumlah tenaga kerja sektor pertanian hanya $12 \%$ dipengaruhi oleh peningkatan produksi Jagung dan $88 \%$ sisanya dipengaruhi oleh faktor yang lain.

Nilai t hitung yang lebih kecil dari $t$ tabel pada tingkat kepercayaan $5 \%(0,24<2,35)$ menunjukan bahwa tidak ada hubungan yang signifikan antara kenaikan produksi Jagung yang diikuti dengan kenaikan jumlah penyerapan tenaga kerja sektor pertanian. Koefisien regresi variabel produksi Jagung sebesar 0,02, berarti jika produksi Jagung mengalami kenaikan sebanyak $1.000 \mathrm{~kg}$, maka hanya akan meningkatkan jumlah penyerapan tenaga kerja sebesar 2 orang, ceteris paribus. Kondisi ini sesuai dengan fakta bahwa Jagung merupakan komoditas yang mudah untuk dibudidayakan, tidak memerlukan pemeliharan yang intensif dan rumit (Sari, 2015).

\section{Perencanaan Pengembangan Kawasasan Budidaya Jagung Untuk Peningkatan Perekonomian Kabupaten Pemalang}

Pengembangan kawasan budidaya Jagung untuk peningkatan perekonomian Kabupaten Pemalang yang disintesiskan hasil dari tujuan peneliatian menghasilkan rencana-rencana sebagai berikut:

Pertama, rencanan pengembangan kawasan budidaya Jagung harus mempertimbangkan aspek biofisik, ketersediaan lahan dan lahan berpotensi cadangan. Penyusunan rencana ini dimaksudkan agar lokasi yang akan dijadikan calon lahan pengembangan kawasan budidaya Jagung tidak bertentangan dengan arahan pola ruang yang tertuang dalam RTRW dan sesuai dengan kriteria kesesuaian lahan untuk budidaya Jagung. Rencana ini menghasilkan prioritas dan alokasi lahan pengembangan kawasan budidaya Jagung di Kabupaten Pemalang.

Penggunaan lahan menjadi acuan utama dalam menentukan prioritas alokasi lahan pengembangan budidaya Jagung di Kabupaten Pemalang, hal ini disebabkan karena hasil analisis kesesuaian lahan berpotensi pengembangan menghasilkan kelas kesesuaian lahan yang sama yaitu S3. Aspek penggunaan lahan juga menggambarkan keuntungan usahatani yang beragam (Tabel 3). Dalam usaha untuk meningkatkan hasil produksi Jagung dan penyarapan tenaga kerja di Kabupaten Pemlang, pemanfaatan lahan Perhutani dapat dijadikan sebagai lahan berpotensi cadangan. Pengembangan kawasan budidaya Jagung di kawasan Perhutani diarahkan mengukuti program PHBM melalui kegiatan tumpangsari. Luas, lokasi dan prioritas rencana pengembangan kawasan budidaya Jagung tersaji pada Tabel 8. Adapun lokasi pengembangan dan urutan prioritasnya secara lebih rinci dapat dilihat pada Gambar 4. 


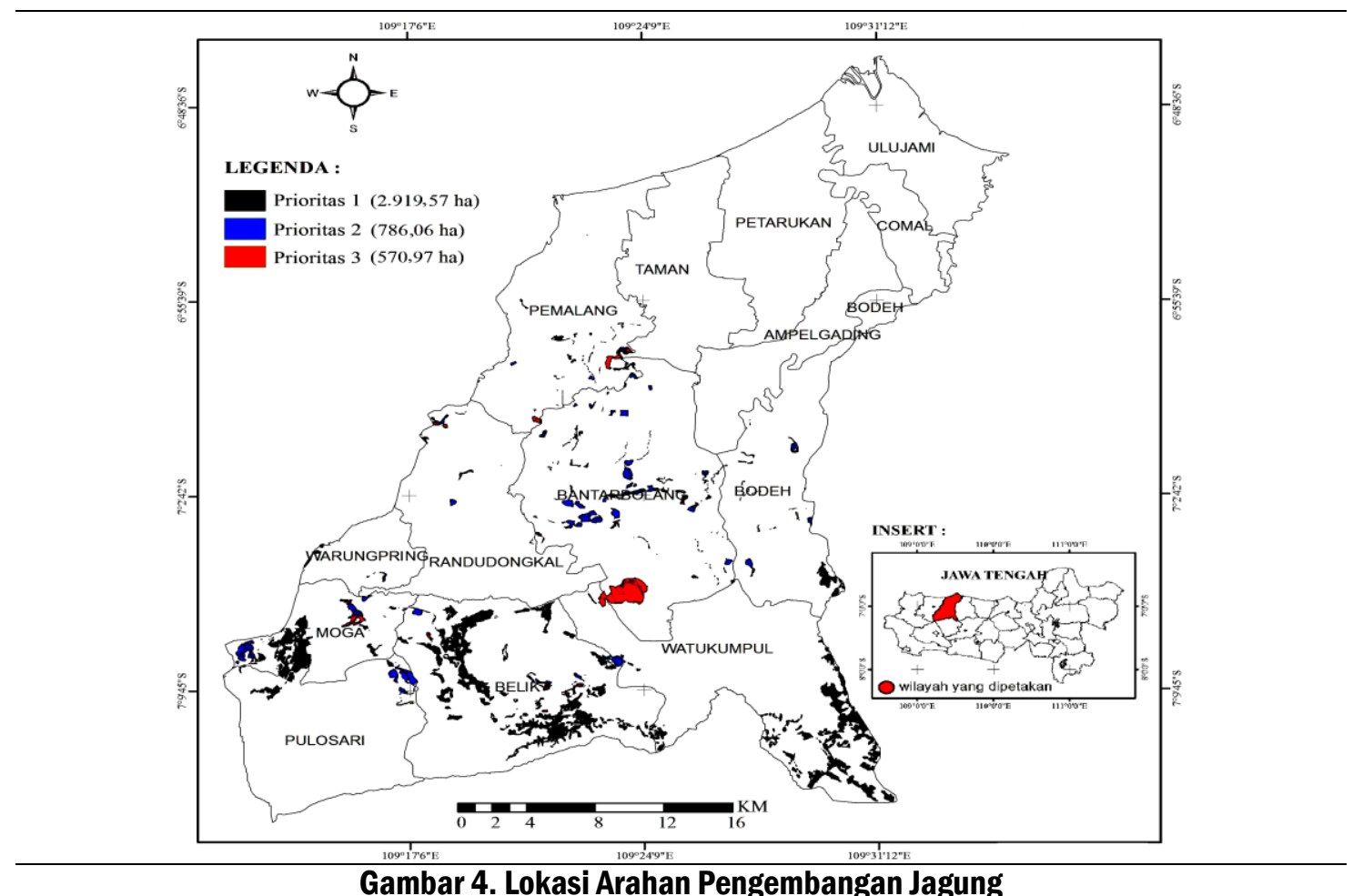

Tabel 9. Matriks Prioritas Lokasi Pengembangan Jagung di Kabupaten Pemalang

\begin{tabular}{lrrrrr}
\hline \multirow{2}{*}{ Kecamatan } & \multicolumn{4}{c}{ Luas (ha) } & \multirow{2}{*}{$\%$} \\
\cline { 2 - 4 } & Prioritas 1 & Prioritas 2 & Prioritas 3 & jumlah & 2,95 \\
Pemalang & 20,04 & 37,22 & 68,81 & 126,07 & 12,89 \\
Poga & 378,41 & 119,59 & 53,29 & 551,29 & 4,36 \\
Belik & 112,52 & 73,52 & 0,39 & 186,43 & 34,63 \\
Watukumpul & 1343,70 & 83,48 & 53,68 & 1480,86 & 22,89 \\
Warungpring & 960,79 & 14,29 & 3,86 & 978,94 & 0,60 \\
Bodeh & 15,59 & 10,01 & - & 25,60 & 3,62 \\
Bantarbolang & 58,95 & 95,28 & 0,54 & 154,77 & 16,71 \\
Randudongkal & 10,99 & 331,79 & 371,81 & 714,59 & 1,36 \\
\hline \multicolumn{1}{c}{ Jumlah } & 18,58 & 20,88 & 18,59 & 58,05 & 100,00 \\
\hline
\end{tabular}

Berdasarkan korelasi antara produksi Jagung dengan peningkatan PDRB sektor pertanian dan penyarapan tenaga kerja diketahui bahwa, pemanfaatan lahan prioritas diprediksi meningkatkan PDRB sektor pertanian sebesar 4,54\% dari capaian awal yaitu Rp 5.490.139.000.000 dan menyerap 76,37\% tenaga kerja atau menyisakan 9.140 tenaga kerja yang masih dapat dipekerjakan. Pemanfaatan lahan Perhutani seluas 285,66 ha sebagai lahan berpotensi cadangan diprediksi meningkatkan PDRB sektor Pertanian menjadi 5,94\% dan menyerap habis tenaga tersisa (pengangguran) di Kabaupaten Pemalang.

Kedua, perencanaan pengembangan kawasan budidaya Jagung harus memperhatikan aspek ekonomi dan pemasaran. Rantai pemasaran yang melibatkan petani, depot dan industri merupakan rantai pemasaran terefisien, memiliki margin yang terkecil dan farmer's share terbesar. Kelancaran arus barang, jasa dan informasi harus dipertahankan karena memberi dukungan positif terhadap pembentukan harga Jagung di tingkat petani yang tampak pada integrasi pasar yang memiliki nilai IMC yang $<1(0,005)$ dan tingkat elastisitas harga Jagung yang mencapai $85,1 \%$. 
Ketiga, perencanaan pengembangan Jagung harus melibatkan peran stakeholder, belum optimalnya peran kelompok tani dan belum dimanfaatkanya keberadaan lembaga keuangan seperti Bank dan Koperasi, membuat petani tidak mempunyai keberanian berspekulasi dalam pengusahaan Jagung. Petani cenderung meminjam talangan modal kepada agen saprodi dan tengkulak dengan perjanjian tertentu. Sehingga kenaikan harga di tingkat industri tidak sampai pada petani karena adanya perjanjian yang telah disepakati.

\section{KESIMPULAN}

Luas eksisting pertanaman Jagung 9,72\% dari luas lahan kering untuk pertanian, memencar di seluruh kecamatan, dengan luas kepemilikan relatif sempit. Lahan berpotensi pengembangan Jagung memiliki kelas kesesuaian lahan sesuai marginal (S3) dengan luas $23,04 \%$ dari luas lahan kering untuk pertanian. Pengembangan Jagung di Kabupaten Pemalang layak dijalankan, pasar Jagung terintegrasi penuh dengan tingkat elastisitas harga yang tinggi. Rantai pemasaran yang melibatkan Petani, Depot, dan Industri memberikan keuntungan maksimal.Terdapat korelasi yang kuat dan signifikan antara peningkatan produksi Jagung dengan peningkatan PDRB sektor pertanian, tetapi berkorelasi lemah dan tidak signifikan dengan kenaikan penyerapan jumlah tenaga kerja. Pengembangan kawasan budidaya Jagung di lahan prioritas dan lahan cadangan diprediksi meningkatkan PDRB sektor pertanian sebesar 5.94\% dan menghabiskan seluruh tenaga kerja yang tersisa di Kabupaten Pemalang.

\section{DAFTAR PUSTAKA}

Alvionita CA, Hamim H, Sembodo DRJ. 2015. Pengaruh Jenis dan Kerapatan Gulma terhadap Pertumbuhan dan Produksi Tanaman Jagung (Zea mays). Jurnal Penelitian Pertanian Terapan. 16(1): 6-13

Amri NA. 2015. Analisis dan Arahan Pengembangan Komoditas Gambir (Uncaria gambier) dalam Rangka Pengembangan Ekonomi Wilayah di Kabupaten Limapuluh Kota. [Tesis]. Bogor (ID): Sekolah Pascasarjana Institut Pertanian Bogor.

Ardani N. 2009. Rantai Pasokan Jagung di Daerah Sentra Produksi Indonesia. Jurnal Pangan. 53(8): 73-85.

Arsyad L. 1999. Ekonomi pembangunan.Yogyakarta (ID): Yayasan Keluarga Pahlawan.

[Bappeda Pemalang] Badan Perencanaan Pembangunan Daerah Kabupaten Pemalang. 2017. Ringkasan Penggunaan Lahan. Pemalang (ID): Bagian Data dan Informasi Bappeda Kabupaten Pemalang.

Bardani Z, Ismail, Kamarubayana L. 2014. Studi Kelayakan Usahatani Karet (Hevea Brasiliensis) di Desa Bunga Putih Kecamatan Marangkayu Kabupaten Kutai Kartanegara. Jurnal Agrifor. 8(2):253-262

Barus B, Panuju DR, Shiddiq D. 2011. Identifikasi Lahan Tersedia dengan Teknologi Informasi Untuk Mendukung Reforma Agraria: Studi Kasus Provinsi Riau dan Jawa Barat. Jurnal Tanah dan Lingkungan. 13(1): 25-34.

[BPS Pemalang] Badan Pusat Statistik Kabupaten Pemalang. 2017. Kabupaten Pemalang dalam Angka 2016. Pemalang (ID): BPS Pemalang.

Cristoporus, Sulaeman. 2009. Analisis Produksi dan Pemasaran Jagung di Desa Labuan Toposo Kecamatan Tawaeli Kabupaten Donggala. Jurnal Agroland. 16(2): 141-147.

Fauziyah. 2011. Integrasi Pasar Ikan Tongkol di PPN Pekalongan dan PPS Nizam Zachman Jakarta. Maspari Journal. 11(3):14-19.

Govind KC, Karki TB, Shrestha J, Achhami BB. Status and Prospects of Maize Research in Nepal. Journal of Maize Research and Development. 1(1):1-9.

Gumma MK, Thenkabail PS, Teluguntla P, Rao MN, Mohammed IA, Whitbread AM. 2016. Mapping RiceFallow Cropland Areas for Shortseason Grain Legumes Intensification in South Asia using MODIS 250m Time-Series Data. International Journal of Digital Earth. 9(10): 981-1003.

Hadijah AD. 2009. Identifikasi Kinerja Usahatani Dan Pemasaran Jagung di Nusa Tenggara Barat di dalam Aqil M, Aruan RY, Rahayu NE, Zainudin B. Editor. Prosiding Seminar Nasional Serealia. 2009 Juli 29. Maros, Indonesia. Jakarta (ID): Badan Penelitian dan Pertanian Kementerian Pertanian. Hlm. 483-490.

Hardjowigeno S, Widiatmaka. 2007. Evaluasi Kesesuaian Lahan dan Perencanaan Tataguna Lahan. Yogyakarta (ID): Gadjah Mada University Press. 
Innocent WI, Emeruem J, Namene N. 2016. Land Value Dynamics in Khana Local Government Area of Rivers State, Nigeria. The International Journal Of Humanities \& Social Studies. 4(8): 113-119.

Jordaan AC, Brost BE, Makguta MA. 2004. Land Value as a Function Distant from CBD, The Case of Suburb of Pretoria. Sajem NS. 2004(3): 532-541.

[Kemendag] Kementerian Perdagangan. 2016. Laporan Akhir: Analisis Rantai Pasok Jagung sebagai Bahan Baku Pakan Ternak. Jakarta (ID): Pusat Pengkajian Perdagangan Dalam Negeri, Kemendag.

[Kementan] Kementerian Pertanian. 2014. Kajian Hasil Inventarisasi LP2B Kabupaten Pemalang Propinsi Jawa Tengah. Jakarta (ID): Subdit Basis Data Lahan Direktorat Perluasan dan Pengeloaan Lahan Kementan.

[Kementan] Kementerian Pertanian. 2016. Outlook Komoditas Pertanian Subsektor Tamanan Pangan.Jakarta (ID): Pusat Data dan Informasi Sistem Pernatian, Kementan.

[Kementan] Kementerian Pertanian. 2017. Fokus Program dan Kegiatan Badan Litbang Pertanian Pengembangan Lahan Sub Optimal.Jakarta (ID): Pusat Data dan Informasi Sistem Pernatian, Kementan.

Kusnanto H, Oktaviani R, Sinaga BM, Firdaus M. 2012. Reindustrialisasi dan Dampaknya Terhadap Ekonomi Makro serta Kinerja Sektor Industri di Indonesia. Jurnal Riset Industri. 6(1): 97-115.

Lee JH, Hwang S. 2014. The Analysis of Distribution and Marketing Margin of Agricultural Products under Different Supply Chains in Korea: In Case of Chinese Cabbage. The International Workshop of SARD (The Society of Asian Retail and Distribution). Bangkok (TH): Kasetsart University.

Mazvimbakupa F, Thembinkosi A, Mabhaudhi T. 2015. Seed Quality and Water Use Characteristics of Maize Landraces Compared with Selected Commercial Hybrids. Chilean JAR. 75(1): 13-20.

Nahdi Z, Hendro HHS, Supriyo H, Solekhan. 2014. Implementasi SIG Untuk Inventarisasi Data Komoditas Pertanian dan Informasi Kondisi Lahan di Kabupaten Kudus. Jurnal Pertanian. 17(1): 79-89.

Nowar W, Baskoro DPT, Tjahjono B. 2015. Analisis Kesesuaian Lahan Komoditas Unggulan dan Arahan Pengembangannya di Wilayah Kabupaten Cianjur. Tataloka. 17(2):87-98.

Nurdina S, Widiatmaka, Munibah K. 2016. Perencanaan Pengembangan Lahan Sawah di Kabupaten Kubu Raya. Jurnal Pengelolaan Sumberdaya Alam dan Lingkungan. 6(1): 1-12.

Oktaviana N, Mulya S, Handayani, Susi, Ani SW. 2008. Analisis Usahatani Kentang (Solanum tuberosum) Var. Atlantik di Gapoktan Barisan Sari Kecamatan Getasan Kab. Semarang. Jurnal Agroland. 15(4):51-56.

Paul S, Uebele M. 2013. Rural Infrastructure and Agricultural Market Integration in the United States: A long run perspective. Discussion Papers on Business and Economics 10. Odense (DK) : Department of Business and Economics Faculty of Social Sciences University of Southern Denmark.

Perera KTGK, Weerasinghe TK. 2014. A Study on the Impacts of Corn cultivation (Zea mays) Family Poaceae on the Properties of Soil. International Journal Scientific and Research Publications. 4(7): 1-6.

[Perhutani] Perusahaan Hutan Negara Indonesia. 2009. Keputusan Direksi Perum Perhutani Nomor 682/Kpts/Dir/2009 tentang Pedoman Pengelolaan Sumberdaya Hutan Bersama Masyarakat. Jakarta (ID): Perhutani.

Ponto SO, Kamenaung A, Wauran P. 2015. Analisis Korelasi Sektor Pertanian Terhadap Tingkat Kemiskinan di Kabupaten Kepulauan Sangihe, Jurnal Efisiensi 15(4): 137-147.

Purba J. 2017. Analisis Komoditas Unggulan dan Arahan Rencana serta Strategi Pengembangannya di Pakpak Bharat Sumatera Utara. [Tesis]. Bogor (ID): Sekolah Pascasarjana Institut Pertanian Bogor.

Purwanto EA. 2007. Mengkaji Potensi Usaha Kecil dan Menengah (UKM) untuk Pembuatan Kebiiakan Anti Kemiskinan di Indonesia. Jurnal.Ilmu Sosial dan Ilmu Politik.10(3): 295-324.

Rustiadi E, Saefulhakim S, Panuju DR. 2011. Perencanaan dan Pengembangan Wilayah. Jakarta (ID): Yayasan Pustaka Obor Indonesia.

Samijan, Budi SC, Joko TP, Ekaningtyas K, Priastuti TR, Bahri S. 2010. Rekomendasi Paket Teknlogi Pertanian Jawa Tengah. Semarang (ID): Dinas Tanaman Pangan Propinsi Jawa Tengah.

Sari MG. 2015. Perencanaan Pengembangan Kawasan Budidaya Jagung Sebagai Bahan Baku Pakan di Kabupaten Ciamis. [Tesis]: Sekolah Pascasarjana Institut Pertanian Bogor.

[Setda Pemalang] Sekretariat Daerah Kabupaten Pemalang. 2011. Peraturan Bupati Pemalang Nomor 3 Tahun 2011 tentang RTRW Kabupaten Pemalang Tahun 2011-2031. Pemalang (ID): Setda Pemalang.

Sitorus SRP. 2004. Evaluasi Sumberdaya Lahan. Bandung (ID): Tarsito.

Suryaningsih, Martin J, Darmadi K. 2011. Inventarisasi Gulma pada Tanaman Jagung (Zea mays) di Lahan Sawah Kelurahan Padang Galak, Denpasar Timur. Jurnal Simbiosis 1(1): 1-8.

Soekartawi. 2006. Agribisnis: Teori dan Aplikasinya. Jakarta (ID): PT. Raja Grafindo Persada.

Suryaningsih, Martin J, Darmadi K. 2011. Inventarisasi Gulma pada Tanaman Jagung (Zea mays) di Lahan Sawah Kelurahan Padang Galak, Denpasar Timur, Provinsi Bali. Jurnal Simbiosis 1(1): 1-8. 
Suryanto, Aryono WB, Sabarnurdin S. 2006. Fallow Land Model in Agroforestry Systems. Journal Tropical Forest Management. 12 (2):15-26

Suwarti, Efendi R, Azrai M, Thahir M. 2013. Pertumbuhan, Hasil dan Indeks Sensitivitas Tanaman Jagung Terhadap Cekaman Genangan Air. Seminar Nasional Serealia. 169-180

Tahir AG, Suddin AF. 2017. Analisis Pendapatan Usahatani Jagung Pada Lahan Sawah dan Tegalan di Kecamatan Ulaweng, Kabupaten Bone Sulawesi Selatan. Jurnal Galung Tropika. 6(1): 1 - 11.

Tshiabukole JPK, Kankolongo AM, Khonde GP, Djamba AM, Vumilia RK, Nkongolo K. 2017. Analysis of Adaptive Response of Maize (Zea mays) Varieties from DR-Congo to Water Stress. American Journal of Plant Sciences. 2017(8): 2282-2295.

Umikalsum RA. 2013. Analisis Pendapatan Dan Kelayakan Ekonomi Usahatani Padi di Daerah Agropolitan Kelurahan Pulokerto Kecamatan Gandus Palembang. Jurnal Ilmiah Agriba.1(1): 14-21

Wida ER, Irianto H, Anam C. 2015. Kajian Identifikasi Pangan Pokok Berbasis Kearifan Lokal pada Rumah Tangga Prasejahtera di Jawa Tengah. Jurnal Agriekonomika. 4(1):66-78.

Widiastuti N, Hasirudin M. 2013. Saluran dan Marjin Pemasaran Jagung di Kabupaten Grobogan. Jurnal Sepa. 9(2): 231-240.

Widiatmaka, Ambarwulan, MJY, Purwanto Y, Setiawan, Efendi H. 2015. Daya dukung lingkungan berbasis Kemampuan Lahan di Tuban Jawa Timur. Jurnal Manusia dan Lingkungan, 22(2): 247-259.

Wirosoedarmo R, Sutanhaji AT, Kumiati E, Wijayanti R. 2011. Evaluasi kesesuaian lahan untuk tanaman jagung menggunakan metode analisis spasial. Jurnal Agritech. 31(1): 71-78.

Yuprin AD. 2009. Analisis Pemasaran Karet di Kabupaten Kapuas. Jurnal Wacana.12(3): 519-538.

Zamhari A. 2017. Analisis Komoditas Unggulan dan Arahan Rencana Pengembangannya di Kota Pagar Alam, Provinsi Sumatera Selatan. Tataloka. 19(3): 192-205. 